\title{
THE COLORADO DOCTRINE OF RIPARIAN RIGHTS, AND SOME UNSETTLED QUES- TIONS.
}

We are developing in Colorado a system of riparian rights, that negatives alike the principles that obtained both under the common and the civil law; a system that is sui generis, and strikingly illustrative of the adaptive tendency of all law to meet natural wants and accommodate itself to particular conditions. The cardinal principles of the system are few and simple, but the application of them to conflicting interests is sometimes difficult. The attention that is now being paid to the reclamation of arid lands by irrigation, the large amount of capital that is being invested in irrigation enterprises, the growing scarcity of water available for such purpose, and the consequent necessity of husbanding and conserving it for beneficial uses, makes the subject an important one. To the lawyer, it is largely an unexplored field. The varied controversies that have already arisen and some that are being foreshadowod have the charm of novelty; and it is worthy of consideration by Colorado lawyers whether a legislative code sufficiently minute and specific to define with reasonable precision these rights and to afford a practical working system for their enforcement is not fast becoming an imperative need.

The Colorado doctrine of riparian rights may be summed up in the statement that riparian proprietors, as such, have no rights; that is to say, they have no usufruct of the waters flowing in the natural streams, not enjoyed by others whose estates are non-riparian. Two sections of the Constitution aptly and tersely express the fundamental lines upon which our system is founded. "The water of every natural stream, not heretofore appropriated, within the State of Colorado, is hereby declared to be the property of the public, and the same is dedicated to the use of the people of the State, subject to appropriation as hereinafter provided." * * * "The right to divert unappropriated waters of any natural stream for beneficial uses shall never be denied. Priority of appropriation shall give the better right as between those using the water for the same purpose; but when the waters of any natural stream are not suffcient for the service of all those desiring the use of the same, 
those using the water for domestic purposes shall have the preference over those claiming for other purposes, and those using for agricultural purposes shall have preference over those using the same for manufacturing purposes."

These provisions deny the existence of riparian rights, except as they rest upon appropriation. The State not only has dominion, but asserts a sovereign ownership over the waters of all natural streams, recognizing at the same time a right of user by those who apply them to domestic, agricultural or manufacturing uses, and without regard to the location of the lands of the appropriator, whether along the stream or remote' therefrom. Indeed, no reason is seen why the waters of one watershed may not be diverted and appropriated for the benefit of lands in another watershed, and such was the decision of the Supreme Court of Colorado in Coffin v. Left Hand Ditch Company, 6 Colo. 433. Certain it is, that no limit can be placed, except that established by nature, upon the quantity of water that may be so diverted, provided it is in good faith, for actual use, and no element of speculation is involved. A proprietorship above or below on the stream, or along or remotely distant from it, in theory gives no advantage. The test of right is dependent on wholly different considerations.

This unlimited doctrine of appropriation has met the strictures of an eminent writer on the subject, Professor Pomeroy, who contends that it violates a primary and natural right, which under all systems of jurisprudence has heretofore received recognition. He asserts a right conferred by natural law whereby those who own lands along a stream should be allowed the use of water as an incident of title, and as a matter of inherent superior advantage over those whose lands do not abut on the stream. The invasion of natural right, as it is termed, involved in the Colorado system, will, he thinks, engender countless strife and controversy in the future and render our whole system a vicious one.

These fears are entirely groundless. The provisions of the Constitution are an organic declaration of what was gezerally considered to be the law from the earliest days of our territorial existence. The titles of lands, riparian and non-riparian, have been almost universally acquired having in view the existence of such a system, ex necessitate rei, and hence it may be said that any element of abstract justice is eliminated from consideration. Nor can it be said that the practical workings of the system show that it is unwise. Questions have arisen, some are settled and some remain unsettled; but they have not 
originated out of the unlimited scope of the doctrine of appropriation, which is the basic principle of the system, and the particular respect calling forth the criticism of Professor Pomeroy. In truth, it is the only system that meets natural conditions, one of which is that the lands on our mesas, more or less remote from the water courses, are frequently the best adapted to agriculture, by reason of the character of the soil, and the availability of natural reservoir sites as strengthening adjuncts of an irrigating system. If proof of this beyond our own experience were needed, the fact that the entire arid region included within the boundaries of New Mexico, Arizona, Utah, Wyoming, Idaho, Dakota and Montana, is practically under the same system, should demonstrate its utility, and its superior adaptation to the wants of the people who are.settling up this growing empire of the West.

It is erroneous, though, to suppose that the doctrine of unlimited appropriation of water is a borrowed one, or that it obtained under any previous system of jurisprudence of which records are extant. It was evolved from the climatic and other natural conditions that characterize the arid plateau of the Rocky Mountain region. Its birth place was here, and it may be said to be indigenous, as it were, to our sectional development. Irrigation, as an art, antedates history. It was practiced by eastern nations from their infancy, and the prehistoric remains of ancient systems attest the stupendous scale on which it was done. Modern works sink into insignificance as compared with the undertakings of the past, whereby water was utilized to make the earth more bountiful. Archæologists are nearly agreed that the cataracts of the Nile are the remains of artificial construction. Nearly equidistant from each other, they served as colossal dams, calculated by close engineering science, partly for the purpose of enabling the waters of the Nile to be diverted even to the confines of the great desert. The records of ancient cities that flourished centuries before Christ, where to-day are but shifting sands, show the powerful agency of these immense public works in creating a vigorous national life and civilization. The prehistoric monuments of the new world, as they are found to-day, in Central America; Mexico and Arizona, exhibit the patient toil and energy of the early races in planning and executing irrigation schemes upon a scale of magnificence. which would cause the modern capitalist to hesitate. In Arizona alone, more than a thousand miles of ancient canals and laterals, built by a forgotten people, in many places excavated through solid 
rock with the crude instruments of the stone age, made possible in a natural desert the means of subsistence for a large population.

Records do not exist that enable us to determine in all cases the system of legal rights by which the diversion and user of water was controlled among these ancient peoples. Among some of them, as in India and Egypt, undoubtedly the state assumed the function of carrying forward these enterprises, and the distribution of water was a matter of state administration, under local rules and usages. Where the community system prevailed, as in the pueblos of Mexico, the water of non-navigable streams along which the pueblos were situate was transferred by the nation to the pueblo authorities, who were entrusted with the division of it for the benefit of settlers. But when we pass from the domain of mere custom to systematized and established law, it is unquestionably true that the unqualified doctrine of appropriation which we have made the keynote of our system, and by which all the waters of a flowing stream may be taken by one who is first in time in making use of them, and without regard to the place of use, formed no part. To a greater or less extent, some recognition was given to riparian ownership, and some attempt made to reconcile the larger use of water for irrigating purposes, especially by proprietors whose estates were remote from the stream, with a primary right existent in the riparian owner to a common enjoyment in the flow of the stream.

Under the common law of England, of course, the doctrine of prior appropriation had no place at all. The owner of land along the stream had a right to the water in its accustomed flow, which was wholly independent of user. It was an incident of his ownership; he could at any time make use of it for all reasonable purposes, in such a manner as not to interfere with the public easement of navigation, returning it to the stream without material change of quantity or quality, and no exclusive appropriation by another could deprive him of this right. It is true that dicta are to be found in some of the earlier English cases, notably Williams v. Morland, 2 Barn. and Cress. 913; Liggins v. Inge, 7 Bing. 692; Bealey v. Shaw, 6 East 207, from which it could be implied that an appropriation by one riparian owner to beneficial use gave an exclusive right as against others; that the water so withdrawn became private property, and only what remained in the stream continued publici juris, but subject to successive appropriations in derogation of the ommon right. This was the arid region doctrine, pure and 
simple, except that the exclusive enjoyment was confirmed to those only whose lands abutted on the streain; and in the case of Lux v. Haggin, 69 Cal. 135 , these early dicta were relied on by counsel as showing that the primitive common law rule was in strict accord with the doctrine that property in the use of water could be acquired by appropriation only. But it is sufficient to say that in the case of Mason v. Hill, 5 Barn. and Adol. I, Chief Justice Denman showed with great wealth of learning that these early expressions of English judges did not correctly state the law of England; and dating from that case, all doubt on the subject was removed, so that the common law as almost universally expounded at the present day negatives the idea of appropriation conferring an exclusive right, except where it rests upon a grant, or upon prescription presumptive of a grant.

Equally, the Roman civil law recognized only a qualified appropriation of water as property, and always "subject to a common right by natural law, where it is capable of being fully enjoyed without exclusive possession." (Bowyer Comm. Mod. Civil Lawe, 64.) Although it is true that in those countries where irrigation received the encouragement of the state, the civil law was accommodated in various ways to existing conditions of soil and climate. In Mexico, for instance, while the common use of waters of unnavigable streams was primarily for all who could gain access to them, yet the government by special concessions in most cases, and in other cases by usages and customs having the force of law, permitted the diversion of the waters of such streams and to that extent the deprivation of the common use, but never in such a way as to despoil a lower estate, and no individual or company not a riparian proprietor could acquire the use of such water "without the previous corresponding permission of the goverment." (Escriche title "Acequia.")

The history of California exhibits the development of a system of water rights, under conditions somewhat similar to those prevailing in Colorado, in which there is a curious blending of the doctrine of appropriation with substantially all the common law incidents of riparian ownership. It is an interesting history, because it illustrates how forcible were the physical conditions of the early settlers in establishing the right to appropriate waters when the lands through which the streams ran were public, and equally how tenacious in the judicial mind was the idea of a common right of enjoyment by the owners along the streams, when the title to such lands became private. When gold was discovered in California in 1848 , and there fol. 
lowed the maddening rush of people from every clime and quarter of the world to wrest a fickle fortune from the "fields," all the land belonged to the United. States, except such private claims as had originated under Mexican sovereignty and were protected by the treaty of acquisition. Necessity with these pioneers was the mother of law-other law they had not. The nationalities were as mixed as in any movement of people the world had ever seen, but the Anglo-Saxon was supreme; and with him came a spirit of fairness, a love of order, and a demand for system that soon crystallized into a code of local rules for the government of all. These rules recognized a priority of right in the first discoverer of a mining claim, and prescribed the conditions under which that right might continue or under which it might be deemed abandoned. As a necessary auxiliary to the exercise of such right, the streams were thrown open and the waters conducted by artificial means to "claims" remote from the banks, and there employed to wash out and separate the virgin gold. Although at first confined in practice to mining purposes, the diversions extended to other utilities, to manufacturing, milling and irrigating. For eighteen years and until the act of Congress of July 26, x866, these possessory rights received no formal sanction from the United States government. So far as any control was vested in the state, they were recognized by various enactments; but as -against the general government, or a patentee under the government, they were absolutely without force; so that a patent to land issuing prior to the act of 1866 was construed by the courts of California and Nevada as vesting the grantee with all the common law incidents of title appertaining to any natural stream coursing through the land, unaffected by any prior appropriation for any purpose. It was said that as long as the lands and waters remained public, they were open to all, and that abstract justice demanded that the first appropriator be protected by according to him a superior right; but when private ownership intervened, the water was held to be an element inseparably connected by the laws of nature with the freehold itself, as much so as the growing timber, and no adverse user, short of a prescriptive right, could derogate from this natural advantage of all whose lands were along the stream. (Vansickle v. Haines, 7 Nev. 249.)

The Statute of Congress passed July 26, s866, recognized and confirmed all rights to the use of water for mining, agricultural, manufacturing and other purposes, acquired by priority of possession on the public lands, whenever such rights are 
acknowledged by local customs and laws, and by the subsequent act of July 9, 1870 , all patents are issued subject to such vested rights.

The California system, therefore, assumed a dual character in which the right of exclusive appropriation had a place, but only in respect to lands which were part of the public domain; and conversely, one who settled upon lands along a stream and acquired the government's title before such priorities attached had a status as at common law, which could not be affected by any subsequent user on the part of others.

The situation was not a logical one. The stern necessities that gave birth to the doctrine of appropriation were permanent in character; they inhere in nature; they were the conditions of the country and its people from which there could be no escape. A custom had grown up wholly irreconcilable with the accepted principles of the common law. It had the sanction of domestic law, and was encouraged by national legislation. It was part of the history of the State, and so acquiesced in. What good reason could there be for confining its scope to public lands, and implanting side by side with it the antagonistic riparian doctrine for private lands? It was an inconsistency that could not withstand the test of experience, and which sooner or later would become intolerable. History has since demonstrated this.

Nevada was in line with California in adhering to the common law doctrine, until in 1889 , in the case of Reno Smelting Company and Reduction Works v. Stevenson, 21 Pac. 3I 7 , the Supreme Court reversed its former rulings, and adopted the principle of prior appropriation as the only one applicable to the use of water in that State. In California, the courts felt constrained to enlarge the reasonable uses which riparian owners might make of the water, so as to authorize diversions for purposes of irrigation, reference being had to the necessities of all other owners along the stream; thus modifying the common law rule, but falling far short of an unqualified acceptance of the principle of appropriation.

We think, then, it must be said that the Colorado system is founded on a salutary principle, which if reasonably administered and applied will produce better results in ultimate wealth and population than any other that could be adopted. But until a legislative code is enacted which will apply in some detail the main underlying principle to the practical situations that are being developed, a grave responsibility rests upon the courts. 
It is a serious question how far the principle of prior appropriation can be carried into practical effect as among the individual consumers of water under the same canal. There should be, and ordinarily there is no difficulty in apportioning the water of a natural stream among the canals taking water therefrom, in the order of their priority. These priorities have been adjudicated, and the executive department of the State undertakes to administer them. With watchful, competent and honest superintendents of irrigation, there is no reason why water can not be divided up in quantities and according to priorities as the courts have established them. In times of shortage, however, the acts of these administrative officials have been oftentimes impeded by writs of injunction. A short lived injunction sued out on behalf of one canal is potent sometimes to disorganize the whole plan of distribution, and give it water to which it is not entitled. A continuance of the injunction for only twenty-four hours may be sufficient to work a grossly inequitable result, and for this reason it behooves the courts to be exceedingly chary in issuing writs which must have the effect of arresting or interfering with the official distribution of water.

Simple as the scheme of distribution is in practice as among canals having their headgates on the same stream, it would be very complex if applied to consumers under the same canal; and it remains an unsettled question whether the priority arising from appropriation and guaranteed by the Constitution extends to such individual consumers. Inasmuch as irrigation is now undertaken by means principally of large canals, from which rights are issued, represented by stock certificates, or contracts, entitling the holder to a certain quantity of water, it is of importance to know whether, if the supply be insufficient for all, the courts will recognize a superior right among some in the order in which they have appropriated their water to individual needs. This question is becoming of greater moment every year, but as yet it is not authoritatively settled.

In contemplation of such state of affairs, the Legislature of 1879 passed an act which provides in effect that the water carried in a canal, if it be less than the full supply to which it is entitled, shall be pro rated among the consumers thereunder, to the end that all may suffer from the deficiency in proportion to their several rights. In the case of The Farmers High Line Canal and Reservoir Co. v. Southworth, I3 Colo. III, the Supreme Court had occasion to consider this act, and the question whether or to what extent it could stand with the constitu- 
tional guaranty of prior right. Each of the three judges filed a separate opinion, and it cannot be said that as a court there was any concurrence of views upon the proposition we have suggested. It seemed to be considered by all that circumstances might exist which would make it the duty of ditch companies to limit the operation of this pro rating Statute by dividing consumers into different classes, having unequal rights; as, for instance, where a canal as originally projected and constructed was afterwards enlarged, and an additional priority acquired on account of the enlarged use. A convenient and perhaps necessary dividing line is thus established, by which the original consumers rank differently from those who should share pro tanto only in the increased capacity. But in the absence of a special feature of that character, does the constitutional mandate require that the holders of water rights under the same canal be accorded priorities among themselves in the order of time in which they have severally begun farming operations? We think it must be said, as was said by Justice Helm in the Southworth case, that the Constitution does not contemplate this. It is entirely impracticable. No such scheme for the distribution of water could be put in successful operation, and, moreover, it would produce results as between consumers of water under different canals which would necessarily defeat the principle itself. If worked out logically, we could look for the utmost confusion in the entire system of administration of water rights. The difficulties are such that it is safe to say the courts will never embark, except to a limited degree, in the undertaking of recognizing individual priorities of consumers under the same canal, or compel the managing officials of such canals so to do in parceling out the water.

We have in Southern Colorado some large tracts of land, the titles of which originated by private grant when this part of the State was under the sovereignty of Mexico. These titles are protected by the obligations of the treaty of Guadaloupe Hidalgo, and in most cases the lands have been segregated from the public domain and evidences of title passed from the United States government to the grantees and their assigns. They have within their boundaries natiral streams, and the contention is made that all the incidents of title under Mexican law attach to these private grants, and that as one of such incidents the owners have absolute control of such waters, irrespective of any user. In other words, that these waters are not impressed with the public character ordained by the Constitution and so subject to appropriation by whomsoever will utilize 
them to beneficial ends; but that the rights thereto became irrevocably fixed under an alien system of jurisprudence. The question is very interesting, and in one aspect opeus up historical inquiry as to the local customs prevailing in the Mexican provinces prior to the cession as respects the diversion of water from natural streams. In another aspect, it involves the supremacy of a State, speaking either by its organic law or through its Legislature, to define and regulate the rights of riparian proprietors, irrespective of the source from which the title of the land is derained. Does the treaty obligation protect simply the title, and is it still with in the jurisdiction of the succeeding sovereignty to provide the rules of law by which such incidents of title as riparian rights shall be exercised? Judge Riner, in the suits instituted by The United States Freehold Land and Emigration Company, in the Circuit Court of the United States, held to that view; but as the cases are now pending on appeal, it may still be considered an unsettled question.

The matter of the greatest practical importance to us in Colorado must always relate to the statutory method's by which the priorities of water rights are adjudicated, and the machinery by which the decrees are enforced. It is something to be regretted that the legislation of $\mathrm{r} 88 \mathrm{I}$ provided for a separate proceeding in each water district, of which there are some sixtyeight in the State. Many of these districts have their source of supply from the same stream or its tributaries, and the consequence has been that the users of water in each district have, at considerable expense, proved their claims and obtained awards of priority, which, while conclusive upon others in the same district, have no strict legal force as against consumers in other districts. It would have been infinitely better if each adjudication had been coextensive with a certain drainage area, as, for instance, the six divisions embracing the waters of the Platte, Arkansas, Rio Grande, San Juan, Grand and Green rivers. The priorities as then determined would be res adjudicata as against all who take from the same natural stream or any of its tributaries. No contention could then be made that the court in one district was over prodigal in allowing claims to the prejudice of appropriators in another district, and we would have had much greater uniformity in the allotment of water on a basis proportionate to actual needs.

These adjudications were made in many cases before the growing scarcity of water became so keenly felt as at present, and it must be admitted that some of our courts recognized very extravagant claims, predicated not upon actual user, but on the 
carrying capacity of the ditches. The fault was largely in the system, which, without scientific data as to the normal supply of water in any given stream, and without a uniform standard of measurement, imposed upon the district judges throughout the State the duty of passing upon these claims. The consequence has been quite anomalous, for it is well known that in many cases the natural streams are not capable of carrying the aggregate amounts of water that have been adjudged to claimants, all of which, in theory at least, are, or should be, based upon actual beneficial user.

A board of control organized as a branch of the executive department, would have been much better competent to deal with these questions of allotment; and with appropriate provisions for an appeal to the courts in a controverted matter, we would have had greater uniformity, a more conservative distribution of water, and a degree of finality in the settlement of claims which we do not have now. This in a general way is the framework of the Wyoming system, which works well in practice, and ought to serve as a model hereafter throughout the arid region, where no system has yet been adopted.

In Colorado it is too late to change to the system of State control. We traveled on a certain road, and cannot turn back. Rights have become measurably fixed, and we must look to the courts to finally correct many of the glaring extravagances which have at times prevailed in the adjudication of water rights. This can only be done by holding fast to the constitutional idea that the right must be commensurate with the use, and by refusing recognition to whatever has the slightest appearance of speculation.

Charles E. Gast. 